\title{
家鶏における母鶏より篗への日本脳炎血球凝集抑 制抗体の移行に関する研究
}

(日本脳炎の疫学的研究一第12報一) *

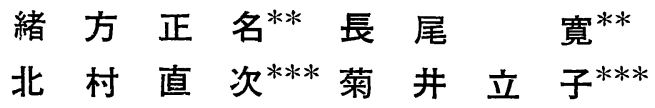

Summary

We could obtain the chiken by artificial fertilization from the hen (White Leghorn) having hemagglutination-inhibition antibody induced by natural infection of Japanese encephalitis. And the rates of disappearance of maternal antibody in chickens were examined.

The results obtained were as follows.

1) Linearity of the semilogarithmic plots of antibody titer in the chicken against the time was proved.

2) Hemagglutination-inhibition titer of maternal antibody at the time of hatch as obtained by extrapolation was about $1: 600$. The value was the same as that of maternal hen.

3) A half life of hemagglutination-inhibition antibody in the chicken was proved to be 4 days.

4) Hemagglutination-inhibition antibody in the chicken was proved to exist mainly in $\gamma$-globulin fraction by starch block electrophoresis.

5) From the above results we must take chicken into consideration as an amplifier of Japanese encephalitis virus.

緒 言

母鶏の抗体が卵を経て雏に移行するてとは S. Pullorum 等1)を始めとして一般に知られている。そし て日本脳炎の抗体が母:鳥から卵を経て雛鳥に移行するて とについては, Buescher, Scherer 等2) の, ごいさぎ, 白 さぎに执いて中和抗体が䳕鳥へ移行する現象を調べた研 究がある。

然しながら自然感染をした家鶏の母体免疫がどのよう に，濰鳥に移り，どのような運命を経るかという点につ いての研究は未だ行なわれていない。私達は前報3にお いて, 家鷄に自然感染によって 2-ME 感受性抗体が産 出され，2-ME 耐性抗体に移行することを述べた。今回 は自然感染によって日脳血球凝集反応抑制抗体価 (HI 抗体価) 1 : 1280を有する雌䳕を選び，乙れに人工授精を 行ない, 卯化後の襍について日数を追って日本脳炎 HI 抗体の減少度を測定したのでここに発表する。

\section{実験材料並びに実験方法}

実験材料 : 岡山県内の流行地に扔いて HI 抗体価が 1

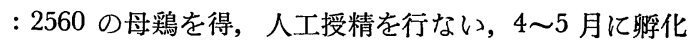
した濰について頸静脉及び翼下静脉より採血を行なっ た。

実験方法：1）家鷄及び雛血清の日脳 HI 抗体価の 測定：すべて国立予防衛生研究所法 ${ }^{4)}$ 亿従った。抗原は Jagar \#01 株を用い，血清はアセトン処理法により血清 中の非特異凝集抑制体を除去したものを用い，血球とし ては 1 日雛血球を用いた。

2) 血清の $2-\mathrm{ME}$ 処理 ${ }^{5)}:$ 血清 $0.2 \mathrm{ml}$ を取り, これ 飞等量の $0.2 \mathrm{M}$ の $2-\mathrm{ME}$ 溶液を加え, $37^{\circ} \mathrm{C} 1$ 時間処理 した後，上記予研法に従い，アセトン処理を行なった 後, 日脳 $\mathrm{HI}$ 抗体価の測定を行なった。

3）殿粉ブロック電気泳動 $\left.{ }^{6}\right)$ : 日本脳炎 HI 抗体を保 有する雛血清 $0.3 \mathrm{~m} l$ を, Holt の veronal-酢酸ソーダ-

* Maternal hemagglutination-inhibition antibodies to Japanese encephalitis virus in domestic chickens. (Part XII of "The epidemiological study of Japanese encephalitis in Japan")

** Masana Ogata and Yutaka Nagao, 岡山大学医学部公衆衛生学教室, Department of Public Health, Okayama University Medical School.

*** Naoji Kitamura and Ritsuko Kikui, 岡山県衛生研究所, Institute of Hygiene, Okayama Prefecture. 
酢酸緩衝液， $\mu=0.045$ を用いて，媣さ $1.0 \mathrm{~cm}$, 幅 1.5 $\mathrm{cm}$, 長さ $35.0 \mathrm{~cm}$ のブロック中で殿粉を支持体として $2 \mathrm{~mA} / \mathrm{cm}^{2}$ で冷凍室中 $4^{\circ} \mathrm{C}$ で 27 時間電気泳動を行なっ た。泳動後, ブロックを電流の方向に直角に $1.0 \mathrm{~cm}$ 毎 に切断し, 生理的食塩水 $1.0 \mathrm{~m} l$ を 2 回加えて抽出を行

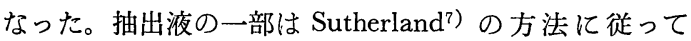
蛋白濃度の測定に, 他の一部は日本脳炎 $\mathrm{HI}$ 反応に使用 した。

\section{実 験 成 績}

1) 日脳 $\mathrm{HI}$ 抗体価の推移：〔図 1〕は瞬化後の日数 における HI 抗体価を示したものである。本図より外插 法で算出すれば HI 抗体価は脬化直後には 1:600 と推 定され，又それは餒化後 38 日で消失する。そして孵化
後の日数を横軸に，抗体価の対数を縦軸にとり，瞬化後 各日の雛の抗体価を plot すれば，抗体価の対数值は日 数に対し直線関係を示しながら減少する。乙れは一般の 血清蛋白の減衰直線とほぼ等しい。しかしながら本図よ り測定した雛の HI 抗体の半減期は 4 日であり, gly- $\mathrm{N}^{15}$ で測定した人血清 $\gamma$-glob の半減期 19 日8) $^{8}$ 亿比べれば 極めて早く, L-methionine $S^{35}$ で測定した $\gamma$-glob の半 減期，3.2日9) 亿近いと考えられる。な怙本図には 4 月 11日，4月21日，5月 2 日， 6 月 1 日に睬化した雛の HI 抗体価を併せて記入しているが，母鷄の HI 抗体価は後 述の如く, 4 月 20 は 1:640,7月 10 日は 1:640であっ て, その間の母鶏の $\mathrm{HI}$ 抗体価の変動は認められていな い。

2）家鶏の母鵎及び觹血清中の HI 抗体に対する

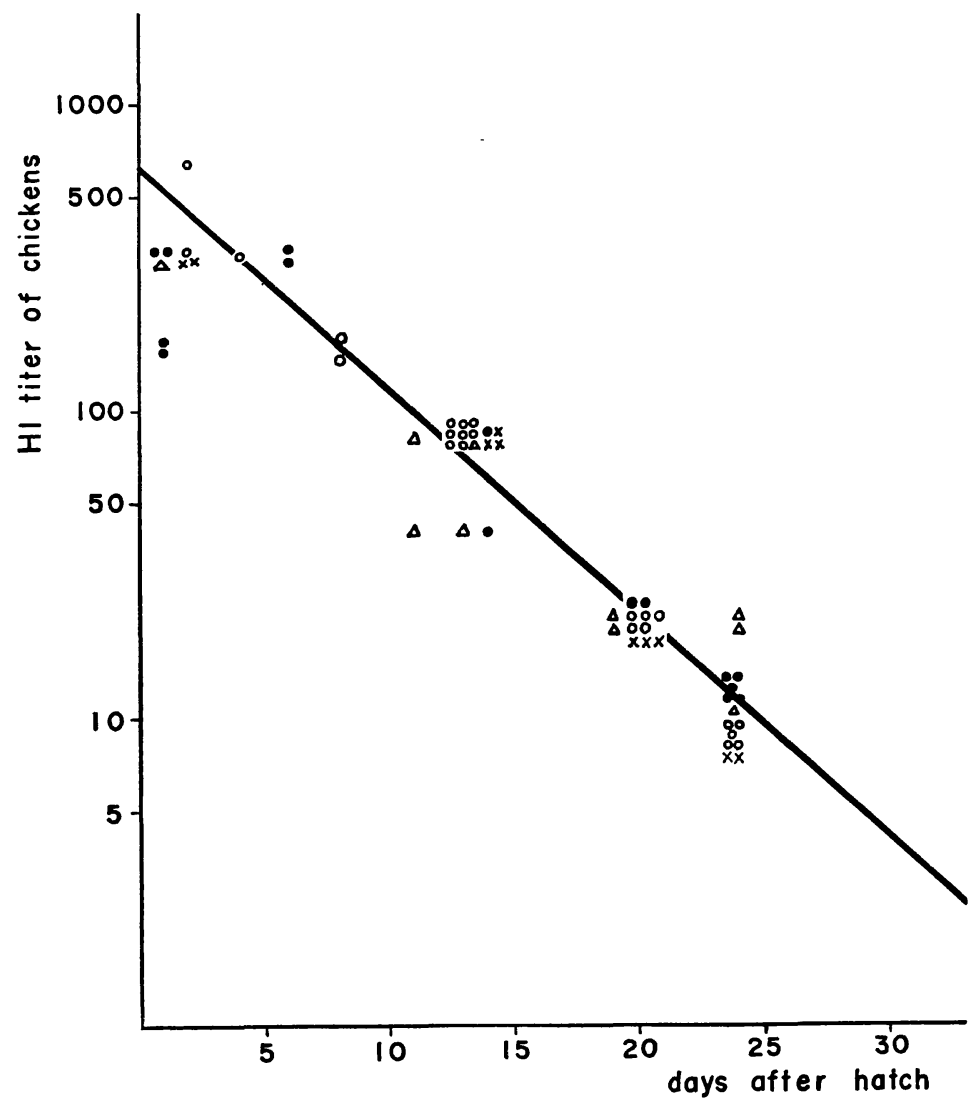

図1. 雛の日本脳炎 $\mathrm{HI}$ 抗体の消長

雛の餒化日 4 月 11 日, $\triangle 4$ 月 21 日, $\bigcirc 5$ 月 2 日, $\times 6$ 月 1 日

Fig 1. Rate of disappearance of maternal Japanese encephalitis virus hemagglutination inhibition antibody from the chickens. Chicken hatched on lst April $\rightarrow 0$, 21st April $\rightarrow \triangle$, 2nd May $\rightarrow \bigcirc$, lst June $\rightarrow \times$. 
表 1. 2-ME 処理前後の HI 抗体価

Table 1. HI titer in the treatment with 2-ME.

A. HI titer of hen

\begin{tabular}{l|c|c}
\hline \hline \multirow{2}{*}{ Date of exam. } & \multicolumn{2}{|c}{ HI titer } \\
\cline { 2 - 3 } & Original serum & $\begin{array}{c}\text { With 2-ME } \\
\text { treatment }\end{array}$ \\
\hline 28 / XI / 1966 & $1: 2560$ & \\
$12 /$ XII / 1966 & $1: 1280$ & $1: 640$ \\
$25 /$ I / 1967 & $1: 640$ & $1: 320$ \\
$20 /$ IV / 1967 & $1: 640$ & $1: 320$ \\
$10 /$ VII / 1967 & $1: 640$ & $1: 320$ \\
\hline
\end{tabular}

B. HI titer of chicken

\begin{tabular}{|c|c|}
\hline $\begin{array}{c}\text { No change by treatment } \\
\text { with } 2-\mathrm{ME}^{*}\end{array}$ & 4 \\
\hline $\begin{array}{c}50 \% \text { decrease by treatment } \\
\text { with } 2-\mathrm{ME}\end{array}$ & 18 \\
\hline Total number of cases & 22 \\
\hline
\end{tabular}

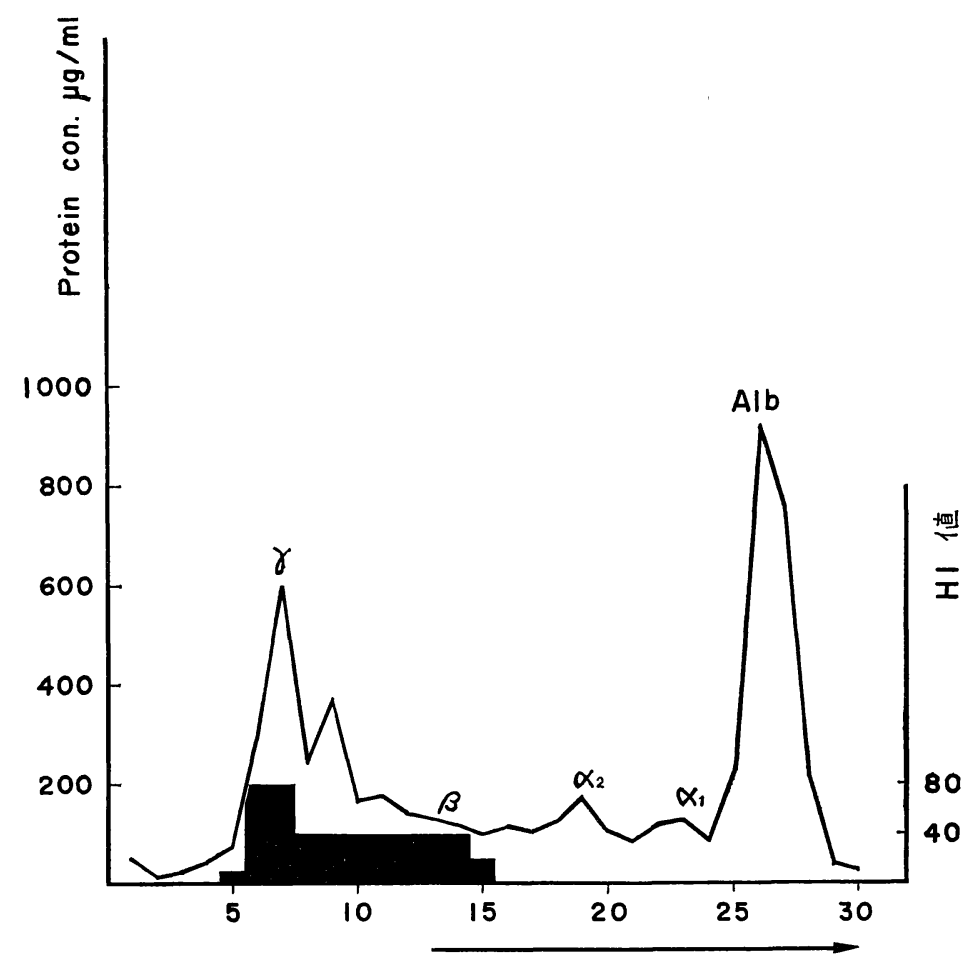

図 2 雛血清の殿粉ブロック電気泳動に㧍ける $\mathrm{HI}$ 抗体存在，黒線 は蛋白量，黒柱は HI 值を示す。

Fig. 2. Distribution of $\mathrm{HI}$ antibody of Japanese encephalitis in chicken serum by starch block electrophoresis. Black line indicates protein concentration, and black column, HI titer.

2-ME 処理の影響 :〔表 1〕亿示す如く原血清の HI 抗 体価は 1:2560以上であったが, その後漸次減少し，12月 $1: 1280,1$ 月 $1: 640,4$ 月 $1: 640,7$ 月 $1: 640$ を示した。 なお 2-ME 処理後の $\mathrm{HI}$ 抗体価は約 2 分の 1 亿減少し た。雛では, 2-ME 処理後の抗体価は, 2 分の 1 に減少 を示すか又はほぼ等しい抗体価を示していた。との点の 詳細については現在研究中である。

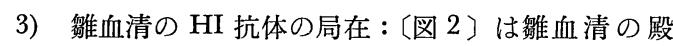

粉ブロック電気泳動の成績を示す。使用血清は HI 抗体 価 $1: 320$ のむのであった。HI 抗体の分布は,家鶏血清の 殿粉ブロック電気泳動の例尚) 亿比べてやや巾が広いが主 として $\gamma$-glob に位置していた。な打血清分画中の $\gamma$-glob 量については, 捊化後, 2 日の雛に比べて 3 週間の雛に おいて, それが抗体と同様にやや減少することについて は, Heim 等 ${ }^{10)}$ の実験がある。また鷄血清の電気泳動 像に扔いて, $\beta$-glob と $\gamma$-glob の分離が完全でなく, 日 
令に従って $\beta+\gamma$-glob 分画の成分比が増加することは 田中 ${ }^{11)}$ が報告を行なっている。

\section{考按}

既報3)の研究によって家鷄が日本脳炎に自然感染をう けて血中に HI 抗体を産生し，それが 2-ME 感受性抗 体より 2-ME 耐性抗体に移行することが明らかとなっ たが, 今回更にその抗体が卵を経て雛に移行し, 母体免 疫として雏が日本脳炎の感染から守られていることが明 らかとなった。そして家鷄の雛は日脳感染マウスの脳を 接種後に, $2 \sim 5$ 日の間 virus 血症を起すこと视) が知ら れているので, 家鶏は日本脳炎の増幅動物として無視で きないあのと考えられる。一方において，母鵎に抗体が 保有されている場合, 雛自身が日本脳炎の母体免疫を受 けることによって自然感染から守られていると考えるこ とが出来る。な幏鷄において，母鷄より Salmonella 抗 体が主として卵黄を通して, 胚, 従って雛に母体免疫抗 体として移行する可能性については渡辺等 ${ }^{1)}$ の成績があ る。

\section{結論}

私共は日本脳炎の自然感染をうけ，高い抗体価を持っ ている家鶏の母鶏を人工授精法によって餒化した雊血清 中の日本脳炎母体免疫による日本脳炎 HI 抗体価の減少 度を調べた。その成績は以下に示す如くである。

1) 雛の生後日数に従って血中 $\mathrm{HI}$ 抗体価の対数は直 線関係を保ちながら減少する。

2）母体免疫による日本脳炎 HI 抗体価の半減期は 4 日であった。

3) 雛血清の HI 抗体は主として $\gamma$-glob 分画に存在 した。

4) 上述の成績は家鶏に日本脳炎 HI 抗体の生成, 従 って家鶏の日本脳炎の感染を確認させるものである。そ して雛に virus 血症を生ずる Buescher 等 ${ }^{12)}$ の成績と併 せ考えて，家鶏は日本脳炎の増幅動物として無視出来な いものと認める。

\section{文献}

1) 渡辺正太他：孵化鷄卵つ Salmonella 感染に関す る研究, 特に S. Pullorum と S. Senftenberg に対す る感染態度の差異, VII. S. Pullorum 感染鶏から卵 への凝集素之免疫的抵抗性の移行, Studies on Salmonella Infection in Hen's Eggs during Incubation with Special Reference to the Mode of Infection with S. Pullorum and S. Senftenberg; Bull. N. I. A. H., 39, 37 (1960)

2) E. L. Buescher, W. F. Scherer, M. Z. Rosenberg, L.
J. Kutner and H. E. McClure: Immunologic Studies of Japanese encephalitis Virus in Japan, J. Immunol., IV, Maternal antibody in birds, 83 (6), 614 (1959)

3) 緒方正名，長尾寞，北村直次：鳥類及び日本脳 炎患者の日本脳炎血球凝集抑制反応に扣ける2Mercaptoethanol 感受性抗体, 特にその存在及び局 在について, 生物物理化学, 12 (3), 187 (1967)

4) 国立予防衛生研究所，ウィルス第 4 室編：日本脳 炎ウィルスの血球凝集反応及び血清診断の為の血球 凝集抑制反応の新しい方法について，国立予防衛生 研究所, 東京 (昭和 37 年)

5）今野二郎他：ブタ及びヒトに扣ける日本脳炎抗体 の季節変動, 医学のあゆみ, 58 (11), 703 (昭和41年)

6) 緒方正名：汇紙電気泳動シンポジウム，第 1 集, 宮本璋，杉本良一編，185，東京，文光堂，(昭和33 年)

7) E. W. Sutherland et al: Purification of the hyperglycemic-glycogenolytic factor from insulin and from gastric mucosa, J. Biol. Chem., 180, 825 (1949)

8) I. M. London, in Youmans, Symposium on Nutrition, II. Plasma proteins, p. 72, G. C. Thomas Publ. Co, Springfield (1950)

9) A. Nikls, W. Maurer: Über die Neubildung einzelner, getrennter Serum-Eiweiß-Franktion nach oraler Gabe von $\mathrm{S}^{35}-1-$ Methionin an Ratten, Biochem. Z. 323 89-103 (1952)

10) W. G. Heim and A. M. Schechtman: Electrophoretic analysis of the serum of the chicken during development, J. Biol. Chem., 209, 241 (1954)

11）田中享一：ニワトリ血清に拈ける電気泳動像と日 令との関係，生物物理化学，8，(4)，155 (1962)

12) E. L. Buescher, W. F. Scherer, M. Z. Rosenberg and H. E. McClure: Immunologic Studies of Japanese Encephalitis virus in Japan, III, Infection and antibody responses of birds 83, (6), 605 (1959) 